(c) American Dairy Science Association, 2005.

\title{
The Balance Between Caseins and Whey Proteins in Cow's Milk Determines its Allergenicity
}

\author{
F. Lara-Villoslada, M. Olivares, and J. Xaus \\ Department of Immunology and Animal Sciences, Puleva Biotech SA, Granada, Spain
}

\begin{abstract}
Cow's milk allergy is quite common in the first years of human life. Protein composition plays an important role in this pathology, particularly the casein/whey protein ratio. It is known that milks from different species have different sensitization capacities although their protein sources are quite similar. Thus, the objective of this work was to compare the allergenicity of native cow's milk and milk with a modified ratio of casein and whey proteins in a murine model of atopy. Twenty-four Balb/c mice were orally sensitized to native cow's milk or modified cow's milk with a casein/whey protein ratio of 40:60. During the sensitization period, the number of mice suffering from diarrhea was significantly higher in the native cow's milk-sensitized group than in the modified milk-sensitized group. Once mice were killed, plasma histamine levels were shown to be significantly higher in native cow's milk-sensitized mice. In addition, cow's milk proteins induced a higher lymphocyte sensitization in the native milk-sensitized mice, with a significant increase in the specific proliferation ratio of these cells.

These results suggest that the balance between caseins and whey proteins plays an important role in the sensitization capacity of cow's milk, and its modification might be a way to reduce the allergenicity of cow's milk. (Key words: casein, whey protein, cow's milk, food allergy)
\end{abstract}

Abbreviation key: $\mathbf{C M}=$ cow's milk, $\mathbf{C M P}=$ cow's milk protein, CMPA = cow's milk protein allergy, $\mathbf{C T}=$ cholera toxin, $\mathbf{M C M}=$ modified cow's milk.

\section{INTRODUCTION}

General food allergies occur in about 5 to $10 \%$ of the infant and small-child populations (Bock, 1987; Sampson, 1997a). Cow's milk protein allergy (CMPA) is the most common allergy in young infants, with an inci-

Received September 7, 2004.

Accepted January 19, 2005.

Corresponding author: Federico Lara-Villoslada; e-mail: flara@ pulevabiotech.es. dence of 2 to $6 \%$ (Hill, 1996; Hosking et al., 2000). This atopic disease is associated with a broad spectrum of IgE-mediated reactions which are mostly expressed as immediate symptoms, such as urticaria, rhinoconjunctivitis, asthma, vomiting, diarrhea and, in the most severe cases, systemic anaphylactic shock and death (Sampson, 1997b).

The best infant nutrition is breast milk, because in addition to having many factors (e.g., IgG, lysozyme, lactoferrin, lactoperoxidase, growth factors) that protect the newborn from the passage of antigens through the gut barrier, its protein is not allergenic to the offspring (Lovegrove et al., 1994; Lonnerdal, 2003). In contrast, cow's milk proteins (CMP) are recognized by the immune system of some newborn infants as foreign proteins, thus causing allergic reactions. The role of different CMP in the origin of CMPA has been studied. Although it is not clear which are the major allergens in cow's milk, several studies demonstrate that most children with CMPA synthesize antibodies principally against $\alpha$-casein and $\beta$-LG (Restani et al., 1999; Bevilacqua et al., 2001; Ametani et al., 2003). Results obtained in our laboratory demonstrated that goat's milk is less allergenic than cow's milk in a murine model of milk atopy (Lara-Villoslada et al., 2004) and we hypothesized that this could be due to the lower amount of $\alpha$ casein in goat milk.

The casein:whey protein ratio in native cow's milk is $80: 20$. Because a reduction of $\alpha$-casein might result in a reduction of allergenicity, it would be interesting to analyze the allergenicity of modified milk with a different balance between casein and whey proteins.

To clarify whether milk with a modified casein:whey protein ratio is less allergenic than native cow's milk, we used a murine model of milk sensitization previously published (Li et al., 1999). This is a model of milk atopy that exhibits the characteristics of type I hypersensitivity reactions. Three-week-old (just after weaning) Balb/ c mice were orally sensitized by administering cow's milk or modified cow's milk plus cholera toxin (CT). Plasma levels of specific $\mathrm{IgG}_{1}$ and histamine concentration were determined, and the role of $\mathrm{T}$ cells involved in the regulation of cow's milk hypersensitivity was investigated by evaluation of the proliferation ratio in spleen cells. 


\section{MATERIALS AND METHODS}

\section{Reagents and Preparation of Milk Samples}

Cholera toxin, concanavalin A, and LPS were purchased from Sigma Chemical Co. (St. Louis, MO). Antibodies for ELISA were purchased from Bethyl Laboratories (Montgomery, TX) for immunoglobulins or from Biosource (Camarillo, CA) for cytokines. The whey protein concentrate was obtained from Arla (Viby, Denmark). All other products were of the best grade available and purchased from Sigma Chemical Co. Deionized water, further purified with a Millipore Milli-Q filter (Bedford, MA) system, was used.

Homogenized cow's milk (CM) was obtained from $\mathrm{Pu}-$ leva Food S.A. (Granada, Spain). A modified cow's milk (MCM) with a casein:whey protein ratio of 40:60 was prepared. Fifty milliliters of CM was mixed with $50 \mathrm{~mL}$ of a lactose solution $(50 \mathrm{mg} / \mathrm{mL})$ to maintain the same lactose concentration as in the original milk. Finally, $1.78 \mathrm{~g}$ of a whey protein concentrate was added to the mixture to modify the milk to a final casein:whey ratio of $40: 60$.

The protein content in $\mathrm{CM}$ and MCM was measured by the Kjeldahl method as previously described (AOAC, 1980). To analyze protein composition of CM and MCM, SDS-PAGE was carried out on a $25-\mu \mathrm{g}$ sample of protein from each milk. Both milks were stored at $-20^{\circ} \mathrm{C}$ in 1$\mathrm{mL}$ aliquots and thawed immediately before sensitization of mice.

\section{Animals}

Female Balb/c mice (3 wk old, immediately after weaning) were purchased from the Granada University breeding colony (Granada, Spain), and housed under a temperature $\left(22^{\circ} \mathrm{C}\right)$ and light-controlled $(12 \mathrm{~h})$ cycle. Animals ( $\mathrm{n}=8$ per group) were maintained on a regular mouse chow diet under specific-pathogen-free conditions. Guidelines for the care and use of animals were followed as described (Institute of Laboratory Animal Resource Commission of Life Sciences, 1996). The global experiment was conducted 3 times with similar results.

\section{Sensitization and Challenge by Oral Administration of Antigen}

Mice were sensitized intragastrically with $\mathrm{CM}$ or MCM, plus CT as an adjuvant, and boosted 5 times at weekly intervals. Oral gavage was performed using a polyvinyl chloride tube-feeding needle purchased from Vygon (Ecoue, France). Mice received $1 \mathrm{mg}$ of CMP (CM group) or MCM protein (MCM group) per gram of $\mathrm{BW}$ together with $0.3 \mu \mathrm{g} / \mathrm{g}$ of CT. To avoid the effect of the adjuvant per se, a group of mice received CT in PBS (control group). Six weeks after the first oral gavage, mice were fasted overnight and challenged intragastrically with 2 doses of CMP (30 mg/mouse) given 30 min apart. Thirty minutes after the last challenge, mice were killed by intraperitoneal administration of sodium pentothal $(50 \mathrm{mg} / \mathrm{kg})$, and blood was collected by cardiac puncture in tubes containing EDTA. Spleen and intestine were removed from each mouse and weighed.

\section{Evaluation of Symptoms}

Gastrointestinal symptoms were evaluated as diarrhea and appeared within $7 \mathrm{~d}$ after the second dose. Animals that suffered from diarrhea on (at least) 2 consecutive occasions were considered positive cases.

Immediately after challenge, hypersensitivity responses were evaluated using a scoring system modified slightly from previous reports ( $\mathrm{Li}$ et al., 1999), and scored as follows: $0=$ no symptoms; $1=$ scratching and rubbing around the nose and head; $2=$ puffiness around the eyes and mouth and pilar erecti; $3=$ decreased activity with increased respiratory rate; $4=$ wheezing and labored respiration; $5=$ cyanosis around the mouth and the tail; and $6=$ death. The evaluation of symptoms was performed by 2 independent investigators who were blinded to the study treatments.

\section{Determination of Plasma Histamine Levels}

Plasma histamine levels were determined using an enzyme immunoassay kit (IBL Laboratories, Hamburg, Germany) following the manufacturer recommendations (Lara-Villoslada et al., 2004).

\section{Measurement of $\beta$-LG-Specific $\lg _{1}$ in Plasma}

Blood was centrifuged $\left(3500 \times g\right.$ for $10 \mathrm{~min}$ at $4^{\circ} \mathrm{C}$, and plasma aliquots were collected and frozen at $-80^{\circ} \mathrm{C}$. Levels of specific IgG Ito $\beta$-LG were measured as previously described (Li et al., 1999). Briefly, 96-well plates were coated with $20 \mu \mathrm{g} / \mathrm{mL}$ of $\beta$-LG in coating buffer (0.5 $\left.M \mathrm{Na}_{2} \mathrm{CO}_{3}\right)$. After overnight incubation at $4^{\circ} \mathrm{C}$, plates were washed 3 times with wash solution $(50 \mathrm{mM}$ Tris, $0.14 M \mathrm{NaCl}, 0.05 \%$ Tween 20) and blocked with blocking solution (50 mM Tris, $0.14 \mathrm{M} \mathrm{NaCl}, 1 \% \mathrm{BSA}$ ). Then, plasma samples were added to the plates and incubated for $1 \mathrm{~h}$ at room temperature $\left(25^{\circ} \mathrm{C}\right)$. Plates were washed 3 times, and $100 \mu \mathrm{L}$ of goat antimouse $\mathrm{IgG}_{1}$ antibody conjugated with peroxidase (Bethyl Laboratories) was added for $1 \mathrm{~h}$ at $25^{\circ} \mathrm{C}$. Staining was performed with 3,3'-5,5'-tetramethyl-benzidine (TMB) (Sigma Chemical Co.) for $30 \mathrm{~min}$ at $25^{\circ} \mathrm{C}$ in the dark, stopped with $0.1 \mathrm{~N} \mathrm{H}_{\mathrm{s}} \mathrm{SO}_{4}$, and plates were read at 450 
$\mathrm{nm}$. Results were expressed as optical density \pm SD. All analyses were performed in duplicate.

\section{Culture of Spleen Cells}

Spleens were removed from all mice 30 min after the last challenge and homogenized in complete culture medium (Dulbecco's Modified Eagle's medium plus 10\% fetal bovine serum with $1 \%$ penicillin/streptomycin). After centrifugation $(1500 \times g, 5 \mathrm{~min})$ erythrocytes were lysed with lysing solution $\left(1.7 \mathrm{M} \mathrm{NH}_{4} \mathrm{Cl}, 0.12 \mathrm{M} \mathrm{KHCO}_{3}\right.$, $0.009 M$ EDTA) for $15 \mathrm{~min}$ at $4^{\circ} \mathrm{C}$. Resting cells were counted using a hemacytometer and cultured to perform proliferation and stimulation assays in complete culture medium (Dulbecco's Modified Eagle's medium $+10 \%$ fetal bovine serum). Cells were incubated at $37^{\circ} \mathrm{C}$ in a humidified $5 \% \mathrm{CO}_{2}$ atmosphere.

\section{Proliferation Assay}

Spleen-derived lymphocytes were cultured in 24-well plates $\left(2 \times 10^{6}\right.$ cells/well $)$ in $1 \mathrm{~mL}$ of medium per well. Lymphocytes from each mouse were divided into 2 wells, one incubated in the absence of proteins (basal), and the other in the presence of CMP $(100 \mu \mathrm{g} / \mathrm{mL}) .\left[{ }^{3} \mathrm{H}\right]-$ Thymidine $(1 \mu \mathrm{Ci} / \mathrm{mL})$ (Amersham Biosciences, Arlington Heights, IL) was added to each well and incubated at $37^{\circ} \mathrm{C}$ in a humidified $5 \% \mathrm{CO}_{2}$ atmosphere. After 48 $\mathrm{h}$, plates were centrifuged $(1500 \times g$ for $5 \mathrm{~min})$ and supernatants were discarded. To fix cells, $500 \mu \mathrm{L}$ of icecold $70 \%$ methanol was added to each well. After 3 washes in ice-cold $10 \%$ TCA, cells were solubilized in $1 \%$ SDS and $0.3 \mathrm{~N} \mathrm{NaOH}$ at $25^{\circ} \mathrm{C}$. Radioactivity was counted by liquid scintillation using a 2100 TriCarb Packard (Meridien, CT) scintillation counter. Each sample analysis was performed in duplicate and the results were expressed as the mean $\pm \mathrm{SD}$.

\section{Statistical Analysis}

Statistical significance $(P<0.05)$ was calculated by Student's $t$-test in case of parametric parameters such as the results of ELISA and proliferation assays. All tests were performed with one tail following the 2 -sample equal variance model (homoscedastic). For nonparametric parameters (score, intestine weight/BW ratio, and number of mice with diarrhea), Mann-Whitney or Fisher tests were used to determine statistical significance $(P<0.05)$. Finally, the Spearman test was used for the statistical analysis of the correlation between serum histamine concentration and hypersensitivity score.

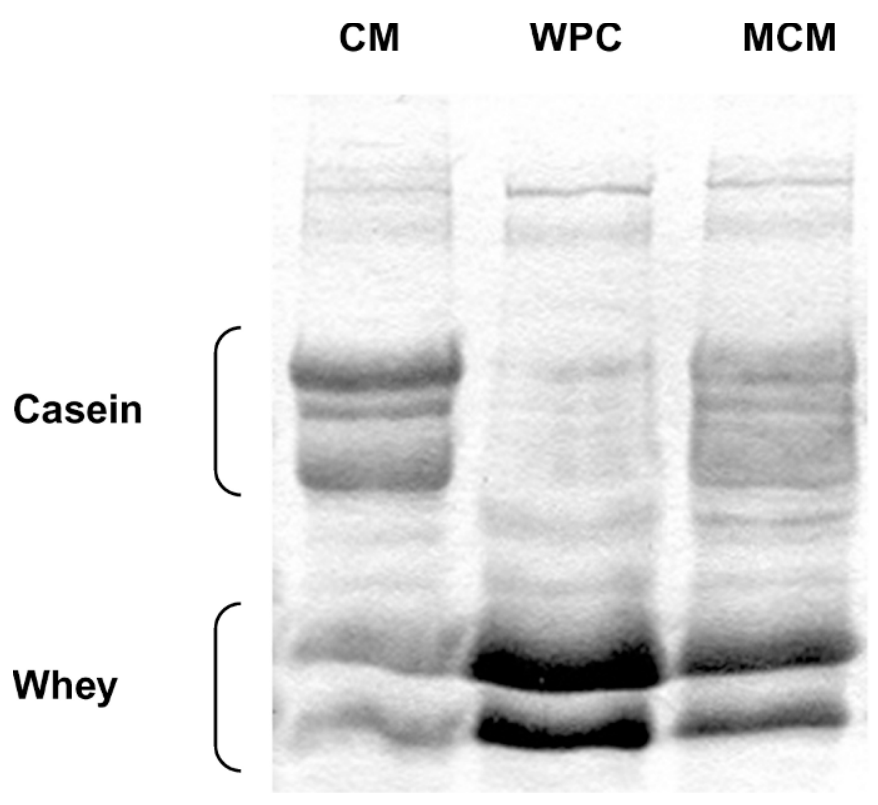

Figure 1. Sodium dodecyl sulfate-PAGE of 2 samples of milk (CM and $\mathrm{MCM}$ ) and a whey protein concentrate (WPC). To analyze protein composition, SDS-PAGE was carried out on $25 \mu \mathrm{g}$ of protein from each milk and the WPC. Protein bands are shown in increasing order of molecular weight. $\mathrm{CM}=$ Cow's milk, $\mathrm{MCM}=$ modified cow's milk.

\section{RESULTS}

Modification of native cow's milk with whey proteins resulted in a milk with the same total protein concentration but a different protein composition. As shown in Figure 1, MCM had lower casein content and higher whey protein content than CM. In contrast, protein concentration measured by the Kjeldahl method was the same in both samples of milk $(29.4 \pm 1.0$ and 29.0 \pm 1.0 for $\mathrm{CM}$ and MCM, respectively).

The percentage of animals with diarrhea was higher in CM-sensitized mice compared with that in the MCMsensitized mice ( $P=0.02$ vs. CM; Table 1$)$. However, it is important to note that diarrhea in both groups was

Table 1. Number of mice suffering from diarrhea $(\mathrm{n}=8$ mice per group). ${ }^{1}$

\begin{tabular}{ll}
\hline Group $^{2}$ & $\begin{array}{l}\text { No. of } \\
\text { mice }(\%)\end{array}$ \\
\hline CT & $1 / 8(12.5)$ \\
CM & $5 / 8(62.5)^{*}$ \\
MCM & $2 / 8(25) \dagger$ \\
\hline
\end{tabular}

${ }^{1}$ Mice were examined weekly by 2 independent investigators for gastrointestinal symptoms Those animals which developed diarrhea in 2 consecutive weeks were considered to be positive cases. Fisher test was used to determine statistical significance $(P<0.05)$.

${ }^{2} \mathrm{CT}=$ Cholera toxin (control) mice, $\mathrm{CM}=$ mice sensitized to cow's milk, $\mathrm{MCM}=$ mice sensitized to modified cow's milk. $* P<0.05$ vs CT; $\uparrow P<0.05$ vs CM. 


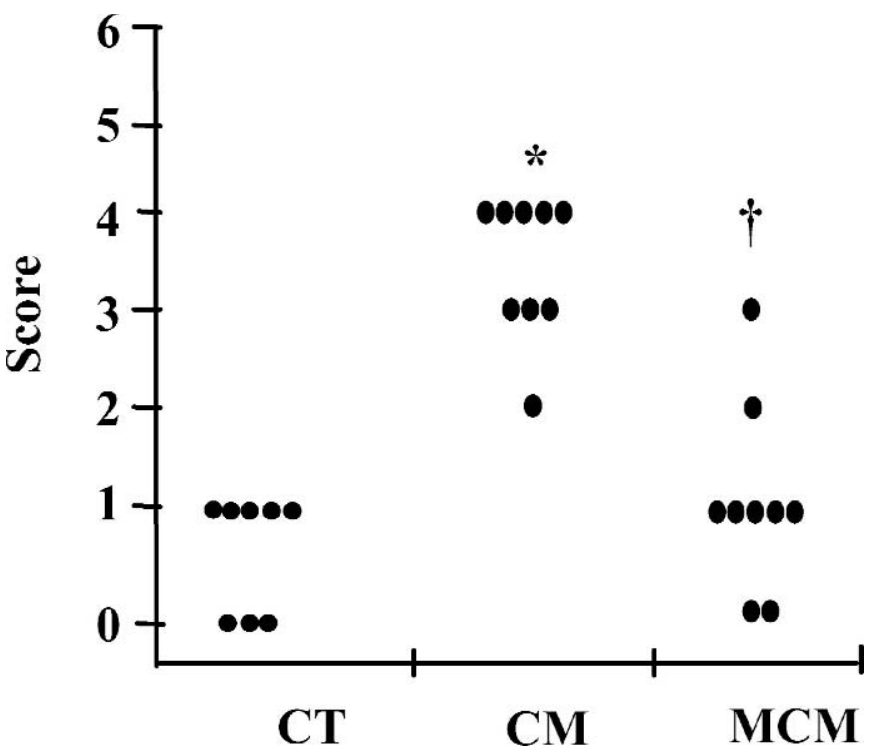

Figure 2. Score of hypersensitivity symptoms. Mice $(n=8$ per group) were challenged intragastrically with cow's milk. Thirty to 40 min later, the symptoms of hypersensitivity were scored on a scale from 0 (no symptoms) to 6 (death) as described in the Material and Methods section. Black circles indicate individual mice from one independent and significant experiment. Mann-Whitney test was performed to determine statistical significance. $* P<0.05$ vs. CT, $\uparrow P<0.05$ vs. $\mathrm{CM}$. $\mathrm{CM}=$ Mice sensitized to cow's milk, $\mathrm{MCM}=$ mice sensitized to modified cow's milk, $\mathrm{CT}=$ cholera toxin control mice.

never so severe as to cause a significant decrease in BW or in food intake (data not shown). We did not expect more severe symptoms because this is a model of milk atopy rather than a model of milk allergy.

After 6 wk of sensitization, mice were challenged intragastrically with CM without CT $(30 \mathrm{mg} / \mathrm{g}$ of BW). Hypersensitivity symptoms became evident within 15 to $30 \mathrm{~min}$. The severity of the reaction was scored as indicated in the Materials and Methods section. Consistent with gastrointestinal symptoms, the most severe reactions were observed in CM-sensitized mice (Figure 2). Mice sensitized with MCM showed weaker reactions, whereas control mice showed no symptoms of hypersensitivity after CMP challenge. Mice in the CT (control) group had a mild reaction, which was probably attributable to weak allergic responses to allergens in food, because of the immunostimulation caused by cholera toxin. The average hypersensitivity score in the CM group was $3.1 \pm 1.1$ which was significantly higher $(P$ $<0.01)$ than that observed in the control group $(0.6 \pm$ $0.5)$. In contrast, the score of the MCM group was 1.1 \pm 0.1 , which was significantly lower $(P<0.01)$ than that of the CM group, but did not differ statistically from that of the CT control group $(P=0.110)$ (Figure 2). Taken together, these results indicate that we achieved

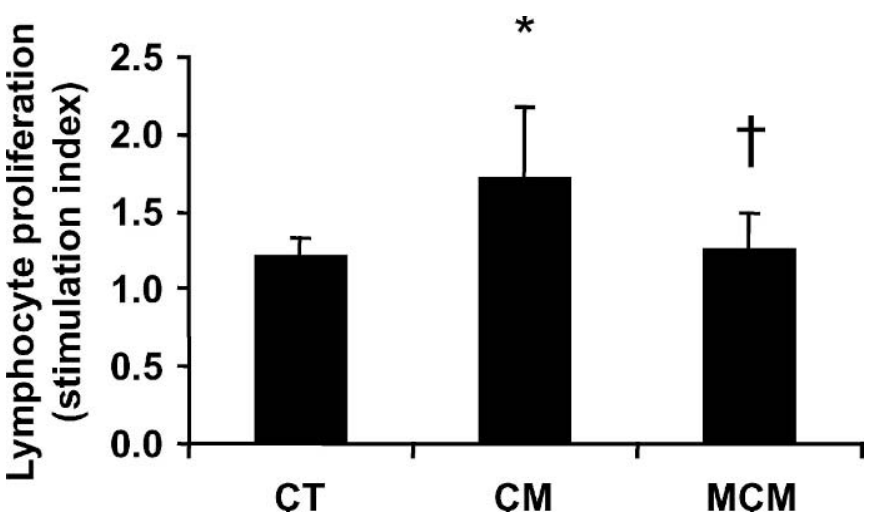

Figure 3. Lymphocyte proliferation assay. Spleen was removed from each mouse ( $n=8$ per group) immediately after killing, erythrocytes were then lysed and spleen derived lymphocytes from each mouse were cultured in the presence or absence of cow's milk proteins (CMP) at $100 \mu \mathrm{g} / \mathrm{mL}$. $\left.{ }^{3} \mathrm{H}\right]$-Thymidine $(1 \mu \mathrm{Ci} / \mathrm{mL})$ was added before incubation for $48 \mathrm{~h}$. Proliferation ratios were determined as $\left[{ }^{3} \mathrm{H}\right]$ thymidine incorporation as described in the Material and Methods section. Results are expressed as stimulation indexes \pm SD: basal $\mathrm{cpm} / \mathrm{CMP}$-stimulated cpm. Student's $t$-test was used to determine statistical significance. $* P<0.05$ vs. $\mathrm{CT}, \dagger P<0.05$ vs. $\mathrm{CM}$. $\mathrm{CM}=$ Mice sensitized to cow's milk, MCM = mice sensitized to modified cow's milk, CT = cholera toxin control mice.

sensitization, which is clearly less important in the MCM group.

Thirty minutes after the second dose of challenge, mice were killed under anesthesia and the intestine of each mouse was removed and weighed. The ratio of intestinal weight to BW was significantly higher in the CM group $(0.12 \pm 0.0)$ compared with the MCM group $(0.10 \pm 0.0)(P<0.01)$ and CT group $(0.10 \pm 0.0)(P<$ 0.01 ), although neither edema nor ulceration was observed. This result might indicate a weak intestinal inflammation caused by CM sensitization consistent with the gastrointestinal symptoms of the CM group.

Because lymphocytes play a key role in the development of CMPA, the spleen from each mouse was removed and weighed. Spleen-derived lymphocytes were counted and cultured to perform proliferation assays and to study their response to different stimuli. Lymphocytes from CM-sensitized mice significantly increased their proliferation ratio when CMP was added to the culture medium (Figure 3). In contrast, CMP failed to induce a significant increase in the proliferation ratio of lymphocytes from the MCM group. However, this increase in the proliferation ratio in the $\mathrm{CM}$ group was not reflected in spleen weight and number of cells, which were similar in all groups (data not shown), suggesting that the number of lymphocytes sensitized to CMP represents a low percentage of total spleen cells.

To study systemic effects of sensitization, plasma was collected from each mouse immediately after sacrifice. Plasma levels of $\beta$-LG-specific IgG $\mathrm{I}_{1}$ were measured by 


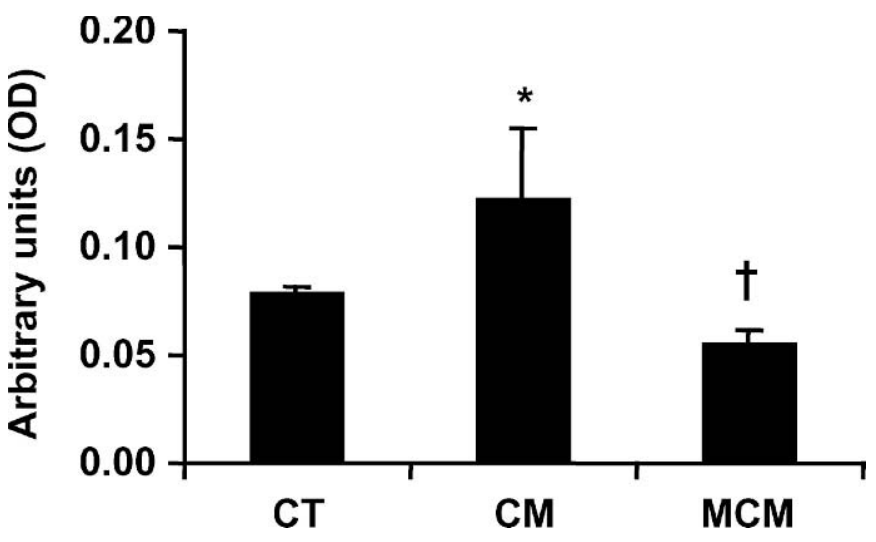

Figure 4. Plasma levels of $\operatorname{IgG}_{1}$ specific to $\beta$-lactoglobulin. Plasma from all mice ( $\mathrm{n}=13$ per group) was collected 30 min after the last challenge. $\beta$-Lactoglobulin IgG $_{1}$ was determined by ELISA. Results are expressed as optical density (OD) values and represented as the mean $\pm \mathrm{SD}$. Student's $t$-test was used to determine statistical significance $(P<0.05)$. $* P<0.05$ vs. $\mathrm{CT}, \dagger P<0.05$ vs. $\mathrm{CM} . \mathrm{CM}=$ Mice sensitized to cow's milk, MCM = mice sensitized to modified cow's milk, $\mathrm{CT}=$ cholera toxin control mice.

ELISA. As shown in Figure 4, CM induced a higher synthesis of specific $\operatorname{IgG}_{1}$ to $\beta$-LG $(P<0.05)$ compared with mice from the control group. In contrast, MCM did not induce such a response, because $\beta$-LG $\mathrm{IgG}_{1}$ levels were similar to those of the control mice. Antigenspecific IgE levels in the same samples were too low to be detected by the ELISA (data not shown). Moreover, no differences were observed in total plasma amount of $\operatorname{IgG}, \mathrm{IgG}_{1}$, or $\mathrm{IgE}$ in all groups (data not shown).

Consistent with these results, plasma levels of histamine were significantly increased $(P<0.01)$ in CMsensitized mice when compared with CT-treated mice (Figure 5). However, the plasma histamine concentration in the MCM group did not differ from that of the CT group $(P=0.07)$. We observed that those mice with a higher score had also the highest levels of histamine liberation $(P<0.01, \mathrm{r}=0.520$; Figure 6$)$, suggesting that the higher histamine liberation was responsible for the symptoms of allergy.

\section{DISCUSSION}

At present, no good animal model exists for studying allergology. We used a previously described animal model (Li et al., 1999) that exhibits the characteristics of type I hypersensitivity reactions, to compare the allergenicity of native and modified cow's milk. The purpose of using this model was to mimic human food allergy by provoking food hypersensitivity by oral ingestion. Other animal models have not been reported to provoke systemic reactions (Ito et al., 1997) or have been induced by parenteral challenge (Poulsen et al.,

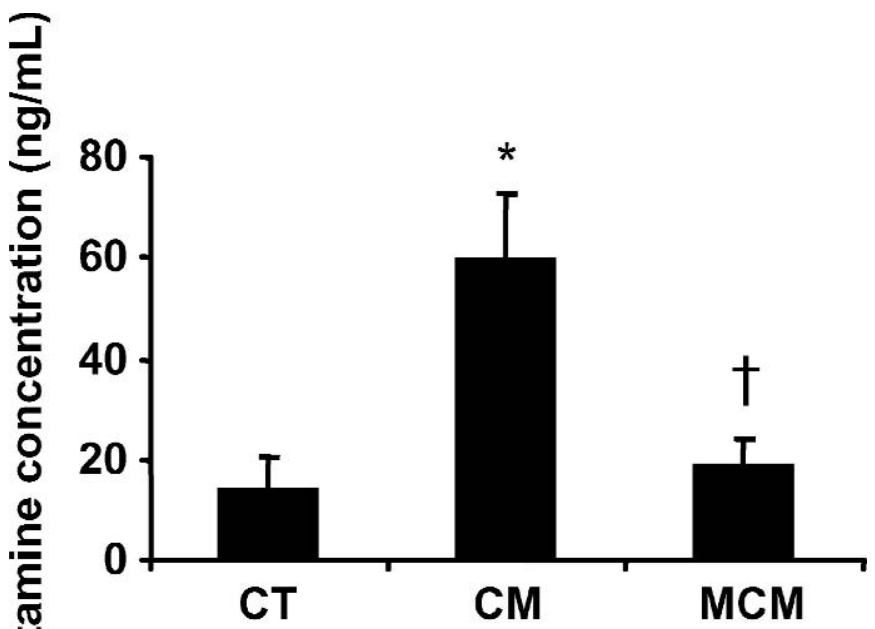

1987), so they did not adequately mimic human food allergy. It is important to note that the animals were used immediately after weaning. Consequently, the first dose of cow's milk was their first contact with CMP and no previous sensitization had been produced. Thus, we ensured that we worked on nonsensitized mice.

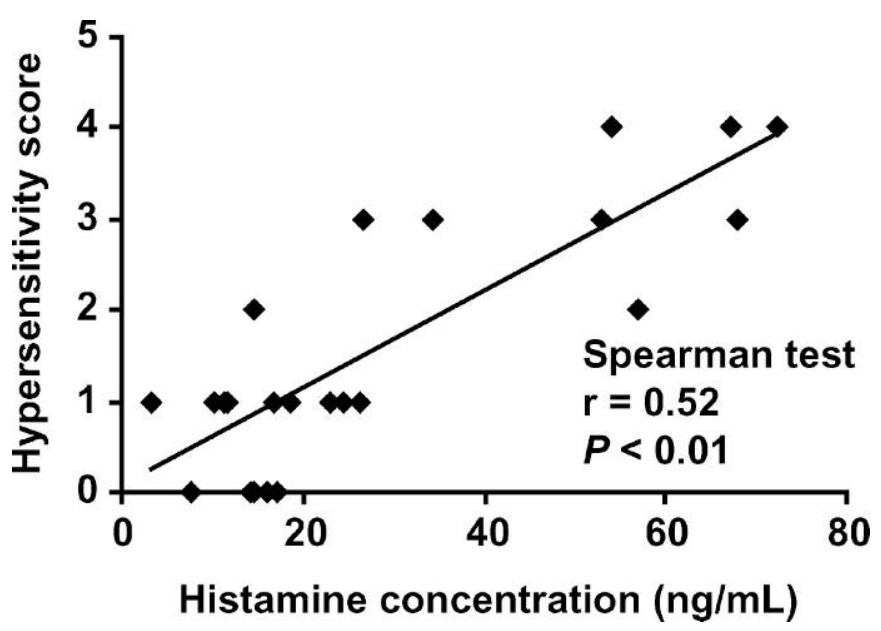

Figure 6. Correlation between plasma histamine concentration and hypersensitivity score. Spearman test was used to determine statistical significance $(P<0.05)$ and the correlation coefficient $(r)$ between plasma levels of histamine and hypersensitivity score 30 min after the last challenge. Black circles indicate individual mice. 
To bypass the tendency of mice to develop oral tolerance, we used CT, which has been reported to stimulate a T helper 2 (Th2) response and the production of $\mathrm{IgG}_{1}$ antibodies (Snider et al., 1994; Marinaro et al., 1995). Furthermore, Balb/c mice were used because this strain of mice is prone to develop Th2 responses more readily than other strains (Sun et al., 2001).

Our results suggest that cow's milk with a casein:whey protein ratio of 40:60 is less allergenic than native cow's milk. In fact, plasma levels of $\mathrm{IgG}_{1}$ to $\beta$-LG and histamine release were lower in the MCM group, in spite of a higher concentration of this protein in MCM, suggesting a less important sensitization in mice from this group. Similar results were obtained with levels of $\mathrm{IgG}_{1}$ to casein (data not shown).

These results were consistent with lymphocyte proliferation in the presence of CMP, because lymphocytes from the MCM group showed a weaker response than those from CM group. Taken together, these results might indicate lesser sensitization capacity of cow's milk with lower casein content.

It is well known that the allergenicity of formulas for infant nutrition is based on protein composition. At present, the most common alternative to conventional cow's milk formula in children with CMPA is extensively hydrolyzed formula, which is based on cow's milk submitted to heat and enzymatic treatment to hydrolyze milk proteins, converting those proteins into low molecular weight peptides (up to $3000 \mathrm{Da}$ ), which do not normally act as allergens. However, several studies demonstrated that such formulas failed to induce the desired level of oral tolerance in rodents (Fritsché et al., 1997; Fritsché, 1998). Partially hydrolyzed formulas are also available, in which the nitrogen source consists of peptides with a molecular weight between 2000 and 10,000 Da. Those formulas have been demonstrated to be better at inducing oral tolerance (Fritsché et al., 1997), but some studies in newborn infants with a high risk of allergies report a higher incidence of clinical manifestations up to 18 mo of age after feeding partially hydrolyzed formulas (Halken et al., 2000). On this basis, our aim was to demonstrate that the modified cow's milk described in this work was less allergenic than native cow's milk, to prevent the initiation of the allergic reaction to CMP.

To our knowledge, this is the first study comparing the allergenicity of 2 cow's milks with differing protein compositions. Surprisingly, cow's milk with a casein:whey protein ratio of 40:60 is normally used in infant formulas, probably to mimic human breast milk; thus, its allergenicity is also reduced, albeit unintentionally.

Previous studies in our laboratory demonstrated that goat's milk is less allergenic than cow's milk (Lara-
Villoslada et al., 2004). We hypothesized that this decrease in allergenicity could be due to the lower content in $\alpha$-casein of goat milk, because it has been previously demonstrated that goat's milk with defective $\alpha$-casein decreases sensitization to $\beta$-LG (Bevilacqua et al., 2001).

The mechanisms by which cow's milk with a lower casein content can be less allergenic than native cow's milk is unknown, but could be related to biochemical interactions between casein and $\beta$-LG. The digestion of $\beta$-LG, a protein known to be resistant to gastric pepsin hydrolysis, might be facilitated by lower casein content, as it is known that caseins and $\beta$-LG are tightly linked into the casein micelles.

It may be that, from an immunological point of view, $\alpha$-casein initiated sensitization due to its potential higher allergenicity, and thus triggered a Th2 response, causing a misbalance between Th1/Th2 immune equilibrium, and so a child would be prone to secondary sensitization by other cow's milk proteins, such as $\beta$ LG. In this sense, the absence or reduction of $\alpha$-casein content might inhibit the initiation of the allergenic course to milk proteins.

Our results are consistent with both hypotheses, because animals from the MCM group have lower levels of $\beta$-LG to $\mathrm{IgG}_{1}$, in spite of the higher concentration of this protein in MCM. This finding is probably due to the lower casein content in MCM.

Finally, another possibility to explain this fact could be related to the intestinal microflora. There is evidence to believe that the fecal flora composition of infants depends on protein quality of infant formulas. Balmer et al. (1989) compared the effect of casein with whey formula and reported significant differences in the fecal flora composition of infants. The number of bifidobacteria and lactobacilli in the whey group exceeded that in the casein group. As it is known that probiotics can reduce the prevalence of atopic disease (Kalliomäki et al., 2001), a formula increasing the number of these beneficial intestinal bacteria could be involved in reducing food allergenicity.

It is important to note that a cow's milk formula with a modified casein/whey protein ratio could be preventive by reducing the incidence of CMPA when given to nonsensitized children. However, children with established CMPA would undoubtedly react against such a formula.

In conclusion, our results might help to elucidate the influence of protein quality in the development of milk sensitization. Further studies are needed to confirm the role of casein and whey proteins in milk allergenicity, as well as the mechanisms to bypass the tendency of the immune system to react against cow's milk proteins. 


\section{REFERENCES}

Ametani, A., T. Sakurai, Y. Katakura, S. Kuhara, H. Hirakawa, T. Hosoi, S. Dosako, and S. Kaminogawa. 2003. Amino acid residue substitution at T-cell determinant-flanking sites in beta-lactoglobulin modulates antigen presentation to T-cells through subtle conformational change. Biosci. Biotechnol. Biochem. 67:15071514

AOAC. 1980. Official Methods of Analysis, 13th ed. Association of Official Analytical Chemists, Washington, DC.

Balmer, S. E., P. H. Scott, and B. A. Wharton. 1989. Diet and faecal flora in the newborn: Casein and whey proteins. Arch. Dis. Child. 64:1678-1684.

Bevilacqua, C., P. Martin, C. Candalh, J. Fauquant, M. Piot, A. M. Roucayrol, F. Pilla, and M. Heyman. 2001. Goat's milk of defective $\alpha_{\mathrm{s} 1}$-casein genotype decreases intestinal and systemic sensitization to $\beta$-lactoglobulin in guinea pigs. J. Dairy Res. 68:217-227.

Bock, S. A. 1987. Prospective appraisal of complaints of adverse reactions to food in children during the first three years of life. Pediatrics 79:683-688.

Fritsché, R. 1998. Induction of oral tolerance to cows' milk proteins in rats fed with protein hydrolysate. Nutr. Res. 18:1335-1342.

Fritsché, R., J. J. Pahud, S. Pecquet, and A. Pfeifer. 1997. Induction of systemic immunological tolerance to beta-lactoglobulin by oral administration of a whey protein hydrolysate. J. Allergy Clin. Immunol. 100:266-273.

Halken, S., K. S. Hansen, H. P. Jacobsen, A. Estmann, A. E. Faelling, L. G. Hansen, S. R. Kier, K. Lassen, M. Lintrup, M. Mortensen, K. K. Ibsen, O. Osterballe, and A. Host. 2000. Comparison of a partially hydrolyzed infant formula with two extensively hydrolyzed formulas for allergy prevention: A prospective randomized study. Pediatr. Allergy Immunol. 11:149-161.

Hill, D. J. 1996. Cow's milk allergy in infancy and early childhood. Clin. Exp. Allergy 26:243-246.

Hosking, C. S., R. G. Heine, and D. J. Hill. 2000. The Melbourne milk allergy study-Two decades of clinical research. Allergy Clin. Immunol. Int. 12:198.

Institute of Laboratory Animal Resource Commission of Life Sciences. 1996. Guide for the care and use of laboratory animals. National Academy Press, Washington, DC.

Ito, K., K. Inagaki-Ohara, S. Murosaki, H. Nishimura, T. Shimokata, and S. Torii. 1997. Murine model of IgE production with a predom- inant Th2-response by feeding protein antigen without adjuvant. Eur. J. Immunol. 27:3427-3437.

Kalliomäki, M., S. Salminen, H. Arvilommi, P. Kero, P. Koskinen, and E. Isolauri. 2001. Probiotics in primary prevention of atopic disease: A randomized placebo-controlled trial. Lancet 357:1076-1079.

Lara-Villoslada, F., M. Olivares, J. Jiménez, J. Boza, and J. Xaus. 2004. Goat milk is less allergenic than cow milk in a murine model of milk atopy. J. Pediatr. Gastroenterol. Nutr. 39:354-360.

Li, X.-M., B. H. Schofield, C.-K. Huang, G. I. Kleiner, and H. A. Sampson. 1999. A murine model of IgE-mediated cow's milk hypersensitivity. J. Allergy Clin. Immunol. 103:206-214.

Lonnerdal, B. 2003. Nutritional and physiologic significance of human milk proteins. Am. J. Clin. Nutr. 77:1537-1543.

Lovegrove, J. A., S. Hampton, and J. B. Morgan. 1994. The immunological and long-term pregnancy and lactation: A pilot study. Br. J. Nutr. 71:223-228.

Marinaro, M., H. F. Staats, T. Hitol, R. J. Jackson, M. Coste, P. N. Boyaka, N. Okahashi, M. Yamamoto, H. Kiyono, and H. Bluethmann. 1995. Mucosal adjuvant effects of cholera toxin in mice results from induction of Thelper 2 (Th2) cells and IL-4. J. Immunol. 155:4621-4629.

Poulsen, O. M., H. Hau, and J. Kollerup. 1987. Effect of homogenization and pasteurization on the allergenicity of bovine milk analysed by a murine anaphylactic shock model. Clin. Allergy $17: 449-458$.

Restani, P., A. Gaiaschi, A. Plebani, B. Beretta, G. Cavagni, A. Fiocchi, C. Poisei, T. Velona, A. G. Ugazio, and C. L. Galii. 1999. Crossreactivity between milk proteins from different animal species. Clin. Exp. Allergy 29:997-1004.

Sampson, H. A. 1997a. Immediate reactions to food in infants and children. Page 169 in Food Allergy: Adverse Reactions to Food and Food Additives. D. D. Metcalfe, H. A. Sampson, and R. A. Simon, ed. Blackwell Scientific Publications, Boston, MA

Sampson, H. A. 1997b. Food allergy. JAMA 278:1888-1894.

Snider, D. P., I. S. Marshall, M. H. Perdue, and H. Liang. 1994. Production of IgE antibody and allergic sensitization of intestinal and peripheral tissues after oral immunization with protein $\mathrm{Ag}$ and cholera toxin. J. Immunol. 153:647-657.

Sun, S., T. Winship, and M. J. Kuchan. 2001. Dietary ribonucleotides modulate type 1 and type 2 responses against OVA in young Balb/ c mice. J. Nutr. 131:1165-1170. 